\title{
THE PROBLEMS OF SEMANTIC EQUIVALENCE IN DIFFERENT TYPES OF UKRAINIAN-POLISH AND POLISH-UKRAINIAN DICTIONARIES
}

\begin{abstract}
This article deals with the problems of semantic equivalence that authors of various types of dictionaries, including bilingual ones, are faced with. Words and phraseological units of common Polish and Ukrainian origin separately developed their systems of meanings in both languages, making it difficult to identify analogues that adequately reflect the semantic structure of linguistic units. In general, the author's assumptions are based on experience of publishing Polish-Ukrainian and Ukrainian-Polish dictionaries of various types.
\end{abstract}

Keywords: dictionary; corpus; equivalence; semantics; word; phraseological unit

\section{1}

The challenge of reflecting the full diversity of word and phraseological unit meanings in a dictionary, and the search for equivalence of language units in bilingual dictionaries, represent urgent tasks for theoretical and applied linguistics. This is especially true at present, when the number of book and electronic dictionary users, and monolingual and bilingual corpus subscribers, has dramatically increased and is constantly growing.

This article is devoted to the problems of Ukrainian-Polish semantic equivalence that lexicographers are faced with. The research is based on, among other sources, the author's, and co-author's, experience of Polish-Ukrainian (Kononenko, Mytnik, \& Wasiak, 2010) and Ukrainian-Polish (Koноненко \& Співак, 2008) specialized dictionary publication, as well as on the book "Ukrainian and Polish languages: contrastive studies" (Кононенко, 2012).

On one hand, the genetic similarity of Ukrainian and Polish, facilitates the identification of lexical and phraseological equivalents. On the other hand, a large number of words and idioms of the same origin have gradually developed their own systems of meanings in both languages, making it difficult to detect analogs that fully reflect the semantic structure of linguistic units.

Contrastive analysis of lexical and phraseological semantics is one of the most pressing and yet scantily explored aspects in the field of Ukrainian-Polish relations and linguistic ties. An important source of research in contrastive linguistics has become new dictionaries, especially electronic ones.

Obviously, bilingual dictionaries are based on the data of monolingual dictionaries. However, modern Ukrainian and Polish explanatory and phraseological dictionaries significantly differ in 
many characteristics. Therefore, it is vital to unify the principles and body structure of dictionaries and their entries on the material of different languages, the selection of illustrative material, solutions to theoretical questions such as the distinction between polysemy and homonymy, definitions to idioms etc. The problems of searching for language counterparts arises in the creation of bilingual dictionaries, as well as synonymous, terminological, phraseological and other types of dictionary.

When composing bilingual dictionaries, lexicographers should pay peculiar attention to words of the same genetic origin in both languages. These words sound similar, but often differ in the composition of components in the semantic structure of the word. Therefore, they often diverge in their compatibility. For example, Ukrainian and Polish verbs that derive from Proto-Slavic sources, and sound almost the same, have obtained completely or partially different metaphorical meanings. Compare: бizamu - biegać - run, мumu - myć - wash, rimamu - latać - fly etc. Divergences in meaning can lead to the incorrect selection of matches in dictionaries. For example, in A. Maletskaia and Z. Landovsky's dictionary the borrowings doktorant \| докторант (Малецька \& Ландовські, 2004) are regarded as analogues, although in fact their equivalents are doktorant || аспірант || postgraduate, докторант \| habilitant || doctoral candidate.

Semantic modifications may occur in borrowed lexemes, including mutual Ukrainian-Polish and Polish-Ukrainian borrowings. In the process of assimilation, under the influence of nationally oriented concepts, words of this type often lose some meanings and acquires others. They can change connotations, which expands or reduces their compatibility. For example, the Polish borrowing in Ukrainian обиватель ( $\leftarrow$ obywaciel - 'citizen') changed its meaning to 'man without broad public opinion, living for small, middle-class interests; citizen' (Кононенко \& Співак, 2008, pp. 179-180); see also: сподіватися $\leftarrow$ spodziewać się - hope, застава $\leftarrow$ zastawa - mortgage and others.

The word кapuй - hazel in Ukrainian means: 1. umber (used with the word eyes); 2. bay (used with the word horse). In Polish, the Ukrainism kary is only combined with words kon and klacz and is synonymous with czarny (Кононенко \& Співак, 2008, p. 125). Compare the semantic changes in Polish words borrowed from the Ukrainian language: komysz, kołomyjka, oprzyszek, wertep, czereda, hulać, bohater, kozak.

In lexicographical sources, lexemes may have similar definitions in two languages but in common usage they partially diverge. For example, according to Ukrainian and Polish explanatory dictionaries, the semantics of the words симпатичний - sympatyczny - nice are very similar. However, word usage examples show that in Ukrainian the word goes with nominations of a person, his/her appearance, or with words of the "human sphere". In contrast, in Polish it is possible to use such complexes as sympatyczna ksiazka, sympatyczna wzmianka, sympatyczne uczucie, sympatyczna atmosfera and so on. The Ukrainian adjective nристойний - decent has a meaning of 'not bad, quite satisfactory', that reveals positive evaluation of a poor degree, e.g. пристойна родина - a decent family, nристойна посада - a decent position. In Polish, the adjective przystojny is of narrower gender compatibility and characterizes the appearance of a man. The word przystojny is much closer to "+" in the valuation scale than the Ukrainian nристойний - decent. Compare: bardzo przystojny facet; Uchodzit za przystojnego.

These examples confirm the view that the meaning of a specific word is to be found in its compatibility. As V. Shyrokov says, "meaning unfolds (becomes apparent) only in context. So, theoretically, for the explication of chosen word meanings it is necessary to collect all — in some sense - contexts where it operates, and to divide them into certain ("semantic") groups, each of which is the representative of a particular lexical meaning. Then, studying these contexts, the lexicographer draws from each group separate lexical meaning of the analyzed lexeme and qualifies appropriate grammatical meanings" (Широков, 2011, p. 262). Thus, changes in the compatibility of Ukrainian and Polish words depict the differences in their meanings, be they significant or highly nuanced. Accordingly, in the search for adequate counterparts in another language it is necessary not only to compare the meaning of words, but also their relevant contexts. 
It should be mentioned that words of the same origin may have equal semantics in Ukrainian and Polish. Generally, monosemic lexemes have much in common, e.g: лінгвістичний \|| lingwistyczny || linguistic, шановний \| szanowny \| dear. According to explanatory and bilingual dictionaries, some lexemes in Ukrainian and Polish belong to a system of similar figurative meanings, e.g: черевик \| trzewik \| boot, вiслюк \| osioł \| donkey, лопатка \| topatka \| scoop and others. However, there are not so many examples of full semantic matching.

In most cases, there is a partial "intersection" (intersection, crossing) of the figurative meanings of words in both languages that have both a common and a different figurative sense. This is evident in the example of the lexeme блискавка - lightning in comparison with its counterparts in Polish:

1. Атмосферне явище \| piorun, błyskawica $\|$ atmospheric phenomena

2. Телеграма \| telegram błyskawiczny, depesza $\|$ telegram

3. Стінна газета \| btyskawica $\|$ the wall paper

4. Застібка || zamek btyskawiczny, suwak \|| fastener.

Many genetically common words of a language have completely different figurative meanings in contrast with the corresponding words in another language, e.g:

Дзвоб $\|$ beak:

1. Elongated thickened part of the bird mouth. The beak of duck.

2. Transp. Tools for work are of the same shape. The beak of machine.

Dziób

1. Elongated thickened part of the bird mouth. Dziob kaczki.

2. coll. The scar on his face. Twarz w dziobach.

3. marine. Forward part of the ship. Dziob statku.

At the lexical and semantic levels of a language system, differences between languages are especially striking, due to the peculiarities of national outlook. Research into the cultural meaning component of words is one of the tasks of modern contrastive semantics. However, people's conversational metaphors, which are an important data medium for language worldview, are largely neglected in explanatory dictionaries, as well as in bilingual dictionaries.

Linguistic metaphors clearly demonstrate the specific worldview of Ukrainians and Poles. For example, in both languages there are appeals to children and loved ones on the basis of animalistic nominations. These notions in Ukrainian and Polish overlap, e.g.: котик, кuи, \| kotek, kicia \| cat, kitty; рибка \| rybka \|fish. However, usage of these secondary nomination entities may be nationally colored; compare the traditional Ukrainian ластівка, ластівочка \| swallow referring to a girl зайчик \| bunny - to the boy, курчатко, горобчик \| chicken, sparrow - to an infant. It would be inappropriate for Ukrainian speakers to address each other using such Polish words as myszka, miś (especially since the misio pet nomination is not just for a boy or man, but also - more recently - girls and women), króliczek, robaczek, żabka and others. Moreover, frogs, mice, and worms have only negative associations in the Ukrainian national consciousness. These metaphorical meanings are generally not mentioned in dictionaries. Thus, in the "Dictionary of Ukrainian language", figurative meanings associated with affectionate appeals are submitted only in the words ластівка, ластів'я \| swallow, baby swallow (Білодід, 1973, p. 452) In the "Uniwersalnemu słowniku języka polskiego" - only figurative meanings for the words miś, misiek are given (Dubisz, 2008, pp. 675-676, 678-679).

The stylistic classification of words can also be inconsistent. For example, the same meaning 'z sympatią o tęgim, często powolnym chłopcu lub mężczyźnie' has the word miś marked pot. pieszcz. żart., and the word misiek - rot. Internet resources are full of texts in which there are numerous linguistic metaphors mentioned above, e.g .: Донечка маленька, чорні оченята, Ти моя красуня, ти моє курчатко (А.Говорадло); Ти мій зайчик (І. Багряний); see also texts of Polish anecdotes that are realia according to Ukrainian language: 
1. - Jak informatycy najczęściej zwracają się do swoich żon?

- Myszko...

2. - Stoneczko...

- Tak, kotku?

- Zrobisz jajeczniczkę, rybko?

- Oczywiście, pieseczku.

- Ale na masełku, żabciu?

— Nie może być inaczej, misiu.

- Myszko... Przyznaj się. Ty też nie pamiętasz, jak mam na imię?

A partial mention of figurative meanings in dictionaries does not promote effective crosscultural communication. One can imagine the difficulties in translation of these examples, particularly in fiction texts. Obviously, colloquial phrases, including metaphorical ones, should be mentioned in dictionaries, including bilingual ones, and in national corpuses.

The phenomena of cross-lingual homonymy and paronymy require special attention. Crosslingual lexical homonyms are identical in sound, but have completely or partially different meanings and usage in both languages, e.g.: диня - melon - dynia. Cross-lingual paronyms are words that sound almost identical and have similar phonetic and morphological forms but are not the same in meaning, е.g: зв'язківець ('працівник зв'язку') - postal (telecommunications worker) zwiazkowiec ('union official').

Cross-lingual homonymy and paronymy are the most common interferential phenomena that may manifest themselves in different speech acts: during the translation of fiction and non-fiction texts, business communication, etc. Evidence of the difficulties caused by cross-lingual homonyms are examples of errors committed by even the most highly-skilled translators, eg: Łąka w kwiatach, nad łąką latające kwiaty, Motyle różnofarbne, niby tęczy kosa... (A. Mickiewicz) \| Мов квіти, що дала природа їм літати, Знялися мотилі веселкою в блакить... (Переклад М. Рильського), e.g: motyl - butterfly, мотиль - mosquito lavra.

Existing Ukrainian-Polish and Polish-Ukrainian dictionaries (in the form of books and electronic editions) do not always contain a full description of the meanings of words which form groups of cross-lingual homonyms, or a description of their lexical and grammatical compatibility. The word eнom - raccoon is matched with the analog jenot in A. Maletskaia and Z. Landovsky's dictionary (Малецька \& Ландовські, 2004, p. 513). This mistake is caused by interference as the result of a similarity in sound but a difference in meaning between Ukrainian and Polish words (correct translation: eнот \| szop).

In order to clarify meanings of words of this type, the "Ukrainian-Polish Dictionary of Crosslingual Homonyms and Paronyms" was created. The dictionary is based on the principle of comprehensively describing a word's semantic structure and its equivalents (meanings) in the other language by demonstrating broad compatibility. The publication contains over 1,400 entries, about 100 of which are dedicated to cross-lingual phraseological homonyms. It was impossible, for reasons of space, to include all cross-lingual homonyms and paronyms, of which several thousand have been identified.

One can observe several types of semantic similarities / differences in cross-lingual homonyms (paronyms).

1. In groups of cross-lingual homonyms (paronyms) there are some units that differ greatly in their semantics, e.g.: вистава - performance - wystawa, чин - rank - czyn, щит - shield - szczyt, чашка - cир - czaszka, ангельсъкий - angelic - angielski. Absolute cross-lingual homonyms in Ukrainian and Polish are rare. This is due to the fact that cross-lingual homonyms (paronyms) in Ukrainian and Polish are mainly of the same origin. The common genetic base ensures common shades of meanings in corresponding lexemes.

2. The greatest difficulties in distinguishing cross-lingual homonyms arise when they belong to the same lexical and semantic group (LSG). In such cases, words in both languages have 
common sences, which may lead to the misunderstanding that they have the same referent. For instance, the words гарбуз - pumpkin and arbuz indicate similar, but different fruits. Compare: гарбуз - pumpkin \| dynia, arbuz $\|$ кавун - watermelon, names of persons, e.g: (гідравлик - hydraulics - hydraulik, доктор - doctor - doctor), food (батон - long loaf - baton, печиво - cookies - pieczywo), household items (диван - sofa - dywan, вазон flowerpot - wazon), clothing (бурка - felt cloak - burka, кітель - tunic - kitel). In such cases the contextual environment doesn't "prompt" meaning, e.g: розмовляти з колегою - to talk with a colleague - rozmawiać z kolega; Kyлuк лemums - stint is flying - Kulik leci and others.

3. Words with partial semantic similarity cause obstacles in both languages too. These lexemes represent the bulk of Ukrainian-Polish cross-lingual homonyms. Cross-lingual homonyms of this type differ in the following categories:

a) in the amount of word semantic structure, i.g.: костьол - church - kоściót, циркон zircon - cyrkon; крушина - buckthorn - kruszyna;

b) in hyper-hiponymous (gender-aspect) correlation, e.g: вуж - serpent - wa z, хрущ,chafer - chrzaszcz;

c) in partial meanings of polyseme words. Typically, these cross-lingual homonyms converge and diverge in figurative (or partially figurative) meanings, e.g: кpymumu - twist - kręcić, корона - crown - korona, дyтuй - exaggerated - dęty;

d) in functional differentiation. In one language, the component of the cross-lingual homonymous group may belong to the active part of lexicon, in the other - to the passive one. There are also cases of word usage in both languages that belong to different functionally limited groups of lexicon, e.g.: вiǔm - chairman (hist., arch.) - wójt (official., hist.).

The specificity of cross-lingual homonym (paronyms) compatibility is beyond doubt, so the "Ukrainian-Polish Dictionary of Cross-lingual Homonyms and Paronyms" demonstrated a wide range of compatibility at the level of syntax constructions of various types and sizes, e.g.: корuсний - поради, птахи, продукти харчування, мед, площа житла; useful - advice, birds, food stuff, honey, medical, housing area; korzystny - interes, wspótpraca, warunki klimatyczne, wywrzeć korzystne wrażenie (Кононенко \& Співак, 2008, pp. 137-138). The dictionary takes into account not only lexicographical sources, but also the phenomenon of modern live speech expressed in journalistic texts, television and radio programs, materials from the Internet, and the national language corpora. Attention was also paid to the frequency of word usage.

Lexical units of Ukrainian and Polish belong to various paradigmatic word groups, including thematic and lexical-semantic groups. The main thematic groups and LSG are universal for all languages, including Ukrainian and Polish. However, the lexical composition of these groups in both languages is different. The specificity of the national and cultural worldview is revealed in the development of certain groups. For example, in the group "family", national specifics are reflected in the denotations of certain family relationships. Thus, Polish words teść, teściowa correspond to тесть, свекор; теща, свекруха - father-in-law, mother-in-law (although in Polish there are the lexemes świekier, świekra, they are at the periphery of usage). However, in the Polish language, traditions differ consistently. Polish distinguishes stryjenka, wujenka, as well as ciocia (ciotka). Ukrainian codified discourse does not focus on their line kinship, only the word mimкa - aunt is an analogue to these Polish lexemes. In language, the most developed type of lexicon is that which is related to the phenomena of high importance for the society (Urbańczyk \& Kucała, 1999, p. 168); See other examples of this lexical-semantic group (Kononenko et al., 2010, pp. 47-50).

The search for equivalents in Ukrainian-Polish and Polish-Ukrainian phraseology is also compli -cated. This is due to specific, complex, metaphorical expression semantics, and to the absence of idiomatic bilingual dictionaries. In addition, appropriate monolingual dictionaries are based on different principles. 
A variety of semantic similarities and differences in idiomatic expressions of the same origin in both languages are revealed through their motivational base observation. The formation of many of the most ancient sayings is common. For example, identical in meaning and motivation are expressions like:

горохом об стіну $\|$ grochem о ścianę

підставити комусь ногу $\|$ podstawić komuś nogę

на кожному кроці \| na kazdym kroku

боятися власної тіні || bać się własnego cienia.

Numerous phraseological expressions in both languages are assimilated in a general sense, but are notable for a component, and thus express a disparity in the metaphorical meanings. The alternative expressions in both languages show the different cultural and historical experience of Ukrainians and Poles, and their specific national identity. Compare, e.g:

не дати собі плюнути в борщ || nie dać sobie w kaszę dmuchnąć

хапатись за соломинку $\|$ chwytać się brzytwy

в сороці народитися $\|$ w czepku się urodzić

бути під каблуком $\|$ być pod pantoflem

курям на сміх $\|$ koń by się uśmiał.

Idiomatic expressions of the same origin in both languages, in comparison with lexemes, differ less in their semantics. Therefore, they demand greater attention.

Some idioms in both languages vary greatly in their meanings, in spite of formal similarity. These expressions form pairs of cross-lingual phraseological homonyms and paronyms. Ukrainian and Polish phraseological material enables one to consider cross-language homonyms (paronyms) as expressions that are similar in sound, lexical components composition, and grammatical structure but with full or partial divergence in semantics.

In I. Kononenko and A. Spivak's "Ukrainian-Polish Dictionary of Cross-lingual Homonyms and Paronyms" semantic differences are mentioned in about a hundred components of phraseological pairs which are similar in composition, e.g:

від руки - od ręki

з години на годину - z godziny na godzinę

набити руку - nabić rękę

пустити око - puścić oko

світити очима - świecić oczyma.

In particular, the Ukrainian language idiom з дня на день means: 1. constantly, all the time; 2 soon, as soon as possible, in the nearest future; Polish $z$ dnia na dzien means: 1. sudden, sharp, fast; 2. gradually. Different meanings in both languages are expressed by the idioms на коня! and na koń! (на коня! [випити] - за благополучну, щасливу дорогу; na koń! - по конях!).

\section{Conclusions}

National language corpora help to reveal the semantic specificity of words and phraseological expressions. It is evident that the bulk of these corpora can be used for word usage illustration in dictionaries, especially in explanatory ones. The corpora also confirm the existence in language of words or idiomatic phrases, which have not been recorded in dictionaries yet. For example, in the corpus of the Ukrainian language, among 50 examples of the word гарбуз - pumpkin in fiction texts, there were 14 idiomatic expressions круглий (округлий) як гарбуз - round (round) like pumpkin (on face, head, body) (Корпус текстів української мови, 2014). Obviously, such a high frequency of usage may result in the inclusion of this comparative expression to the phraseological dictionary. However, in the Ukrainian language corpus a popular idiom дати (піднести) гарбуза, 
which means refusal to get married, is not found. One equivalent of this metaphorical expression in Polish, podać czarna polewke, is not recorded in the Polish national corpus (Narodowy Korpus Języka Polskiego, 2014).

A wide variety of examples illustrating a lack of words, phraseological expressions and their meanings in corpora of different languages can be shown. The question is: How random, and therefore accidental, must the selection of texts be in the corpora? Perhaps texts should not only be selectively placed in corpora from the point of "from speech to language", but also be deliberately chosen via the internet as examples of metaphorical expressions recorded in dictionaries. This approach will lead to a more complete language map, and thus help to create different types of dictionaries, both monolingual and bilingual.

\section{References}

Dubisz, S. (Ed.). (2008). Uniwersalny stownik języka polskiego. Warszawa: PWN.

Kononenko, I., Mytnik, I., \& Wasiak, E. (2010). Stownik Tematyczny polsko-ukraiński. Warszawa: PWN. Narodowy Korpus Języka Polskiego. (2014). Retrieved 10 November 2014, from nkjp.pl

Urbańczyk, S. \& Kucała, M. (Eds.). (1999). Encyklopedia języka polskiego. Wrocław: Zakład Narodowy im. Ossolińskich.

Білодід, I. К. (Ed.). (1973). Словник украӥнсъкої мови (Vol. 4). Київ: Наукова думка.

Кононенко, I. (2012). Украйнсъка та польсъка мови: Контрастивне дослідження. Warszawa: Wydawnictwa Uniwersytetu Warszawskiego.

Кононенко, І. \& Співак, О. (2008). Українсъко-польсъкий словник міжмовних омонімів і паронімів. Київ: Вища школа.

Корпус текстів украӥнсъкої мови. (2014). Retrieved 10 November 2014, from http://www.mova.info/

Малецька, А. \& Ландовські, 3. (2004). Польсько-украӥнський, украйнсько-польський словник. Київ: Перун.

Широков, В. А. (2011). Про деякі аспекти лінгвістичного опису семантики в тлумачному словнику українсъкої мови. In В. Г. Скляренко (Еd.), Життя у слові (pp. 253-270). Київ: Видавничий дім Дмитра Бураго.

\section{References (Transliteration)}

Bilodid, I. K. (Ed.). (1973). Slovnyk ukraïns'koï movy (Vol. 4). Kyïv: Naukova dumka.

Dubisz, S. (Ed.). (2008). Uniwersalny stownik języka polskiego. Warszawa: PWN.

Kononenko, I. (2012). Ukraïns'ka ta pol's'ka movy: Kontrastyvne doslidzhennia. Warszawa: Wydawnictwa Uniwersytetu Warszawskiego.

Kononenko, I. \& Spivak, O. (2008). Ukrä̈n'ko-pol's'kyı̆ slovnyk mizhmovnykh omonimiv i paronimiv. Kyïv: Vyshcha shkola.

Kononenko, I., Mytnik, I., \& Wasiak, E. (2010). Stownik tematyczny polsko-ukraiński. Warszawa: PWN.

Korpus tekstiv ukraïns'koï movy. (2014). Retrieved 10 November 2014, from http://www.mova.info/

Malets'ka, A. \& Landovs'ki, Z. (2004). Pol's'ko-ukraïns'kyı̆, ukrä̈ns'ko-pol's'kyॅ slovnyk. Kyïv: Perun.

Narodowy Korpus Języka Polskiego. (2014). Retrieved 10 November 2014, from nkjp.pl

Shyrokov, V. A. (2011). Pro deiaki aspekty linhvistychnoho opysu semantyky v tlumachnomu slovnyku ukraïns'koï movy. In V. H. Skliarenko (Ed.), ZHittia u slovi (pp. 253-270). Kyïv: Vydavnychyı̆ dim Dmytra Buraho.

Urbańczyk, S. \& Kucała, M. (Eds.). (1999). Encyklopedia języka polskiego. Wrocław: Zakład Narodowy im. Ossolińskich.

\section{Acknowledgment}

This work was supported by a core funding for statutory activities from the Polish Ministry of Science and Higher Education.

The author declares that she has no competing interests. 
This is an Open Access article distributed under the terms of the Creative Commons Attribution 3.0 PL License (http://creativecommons.org/licenses/by/3.0/pl/), which permits redistribution, commercial and noncommercial, provided that the article is properly cited.

$$
\text { (C) The Author } 2016
$$

Publisher: Institute of Slavic Studies, Polish Academy of Sciences, University of Silesia \& The Slavic Foundation 